\title{
Learning and the Determining Factors of Its Quality: An Analysis of the Teacher's and Technology's Role in Gjirokastra
}

\author{
Loreta Mamani \\ «Eqrem Cabej» University, Gjirokastra \\ loretamamani@hotmail.com
}

\section{Doi:10.5901/jesr.2014.v4n1p239}

\section{Abstract}

\begin{abstract}
Although researchers agree that the information and communication technology affects the quality of learning, they don't share the same ideas when it comes to determining whether the quality of learning depends on and is influenced more by the traditional role of the teacher, the role of information and communication technology (ICT), or the combined influence of both. Then to what degree does the quality of learning reflect the role of teachers, ICT, or both of them? This study examines the teaching and learning process in schools in the Gjirokastra county. Its aim is to analyze two issues: 1) What is the level of teaching process in schools of these districts, and 2) If the observed level of teaching process is a result of the role of teachers, of the use of ICT, or of their combined influence. The analysis is conducted and tested using two models: The first model gives priority to the traditional role of the teacher, whereas the second model gives priority to the use of ICT. By using the parameters of the two models this study has arrived at three findings: 1) The quality of teaching process is of an average level; 2) The teacher-centered model is used more than the model that gives priority to ICT; 3) The level of teaching process in schools that give priority to the role of teachers is higher than in schools that possess ICT infrastructure and teaching materials. This study tries to argue that the variation in the quality of teaching process and the influence of teachers and ICT is accounted for by the use of ICT. However positively it may affect the quality of teaching process, the use of ICT remains limited in its influence if not combined with the teacher factor. Knowledge and skills of teachers in using ICT influence the role and impact ICT itself has on the teaching process. The teaching process is more qualitative when it is a result not only of the traditional role of teachers, but also of the effective use and integration of ICT.
\end{abstract}

Keywords: learning, ICT, teacher, teaching model;

\section{Introduction}

One of the goals of the MES since 2004 has been the improvement of the quality of teaching process. That is why the improvements in the education system began precisely with the curriculum revision and modernization of the learning process. ${ }^{1}$ In this context, education should be able to predict the pace of society and prepare citizens to cope with continuous transformation. An important role in improving the education system plays the use of ICT. The ICT strategy in education is now part of the National Inter-Sectorial ICT. One of the goals of MES since 2011 has been to further spread the use of Information Technology and Communication in the school curriculum. Advancement in the field of ICT has been rapid in recent years. In the past, information was scarce, and the only source of information for students was the teacher. Today sources of information are manifold. The school is under the pressure of the need for change. For this to happen, the rapid development of information requires changes in methods and practices in education. MES is working on the compilation of a curriculum, in which the subject of ICT is included since the first grade of primary education. When talking about the introduction of technology in schools, consideration should not only be given to the relationship between student and computer, and a large number of devices like desktop, notebook, digital camera, local networks, Bluetooth, Internet, DVD, etc., and programs like word processing, electronic spreadsheets, tutorial, simulator, emulator, email, digital libraries, but also the way how this technology will be integrated and used to realize the main learning objectives. But ICT is being used as a means for improving the quality of life. Different types of technologies are utilized to help people with various physical or cognitive handicaps. Integrating technology in the curriculum will require periodic re-conception. Attention has to be paid to the effects of technology on our environment. ${ }^{2}$

The focus of this article is the "Teaching process", meaning its quality and character, and whether it is quality or

${ }^{1}$ MES, "National Education Strategy 2004-2015", Tirana, 2004, fq17

${ }^{2}$ Allan Horsten, Francis Hunkins, quoted work, Curriculum, pg 556 
not, or at a high or low level!

The main question and secondary question of this study are:

- What is the level of quality of teaching process in Gjirokastra district?

- What can account for the level of the teaching quality observed in this city?

\subsection{Motivation}

The motivation to address this topic stems from the phenomena observed in the secondary schools of the Gjirokastra district, listed as follows:

- Learning occurs as a phenomenon resembling a variable of dual nature. That is to say that learning appears as the dependent variable, meaning that it is influenced by other phenomena and factors, but also appears as independent variable that has its own effects;

- Observation of three negative phenomena:

- Phenomenon 1: The increase in the role and scope of the use of ICT in the teaching process and in the student's individual activity not always giving optimistic results

- Phenomenon 2: An existing gap between the current education system and growing generation of digital students

- Phenomenon 3: The clash between supporters of the use of ICT, supporters of the teacher-centered teaching process and a third group who require that special attention be given to the needs, abilities and interests of the learners

\subsection{Aim}

This study provides an analysis of the teaching models and factors that influence the quality of learning for the Gjirokastra district.

\subsection{Methodology}

The methodology used in this study is based on the following scientific research methods: Listing of literature, observations in different secondary schools, investigation of the situation, the achievements and defects, free discussions, interviews and surveys with students, teachers, directors and parents to gather their thoughts and opinions about the use of this strategy in school, personal opinion about our experiences and colleagues from work at school. The methodology is based on statistical analysis and comparison. The unit of analysis is the collection and analysis of data.

\subsection{The state of ICT use in schools of Gjirokastra district}

Gjirokastra district, as part of the Albanian education, is involved in the initiative "The integration of ICT in teaching process." To this end, RED has began its work on these plans:

- The highlighting of existing capacities in the Gjirokastra district, who have good knowledge about ICT and the establishment of a staff with training capabilities.

- The training of all teachers in basic computer programs and knowledge of the most basic operating systems.

- The creation of digital libraries in schools.

The RED specialists themselves were trained in these programs and then they started working with groups of teachers according to their needs. Intensive training has been carried out in the Gjirokastra district and at the end of this program teachers took a test organized by AIST (Albanian Institute of Statistics and Technology) and were given a certificate with two credit points. The status of trained teachers is as follows:

Table No.1

\begin{tabular}{|c|c|c|c|c|}
\hline District & Total number of teachers & 2010 & 2011 & Trained teachers \\
\hline Gjirokastra & 357 & 99 & 98 & 197 \\
\hline
\end{tabular}

14 directors have also been trained from EPICT centre. 
Table No.2

\begin{tabular}{|c|c|}
\hline District & Directors \\
\hline Gjirokastra & 7 \\
\hline
\end{tabular}

Then a question naturally arises: How effective are and how have all these trainings influenced the introduction of ICT to teaching process? Important steps to create some digital libraries have been taken in all schools, even though modest ones. Teachers, especially those of Chemistry-Biology, Geography, History are using technology more and more in class. However, the curriculum specialists and teachers should be careful when using technology. Talbot warns us not to get to much enthusiastic about using computers, because, if we use computers or other kind of technology inappropriately, we run the risk of turning our students into the machines, thus ceasing to treat them as individuals, as they really are.$^{3}$ Teachers should use it in order to achieve the educational objectives. There are four qualities that should be considered when using technology in education. First, technology must put human values and educational goals above the on economic goals. Second, teachers should be clear about the educational goals of using technology. Third, its use should not be seen as the quickest solution to the problems of teaching process. Fourth, the means through information is gathered and exchanged should be developed. ${ }^{4}$

\section{What are the Existing Approaches to the Treatment of Teaching Process?}

Although researchers agree that the ICT affects the quality of teaching process, they are divided when it comes to determining whether the quality of learning depends on and is influenced more by the role of the teacher, the role of ICT, or the combined influence of the two. So this phenomenon is viewed from different kinds of approach:

The approach from the technological perspective. This approach builds on the role of:

- $\quad$ Use of ICT by the teacher and student

- $\quad$ Electronic teaching materials

The approach from the teaching content perspective. This approach builds on the role of:

- Teacher

- Pupil

- $\quad$ Teaching process

Some models have emerged from the clash between these approaches: Which models explain the quality of teaching process?

- Model 1: Teaching process ICT

- Model 2: Learning process Teachers + Students + Teaching Process

- Model 3: teaching process ICT + Teachers + Students + Teaching Process

So as it can be seen in diagram, the ICT approach has given rise to the Model 1, the Teachers + Students + Teaching process approach has given rise to Model 2. Because of the discussion generated between Model 1 and Model 2 some researchers highlight the fact that a third model, ICT + Teachers + Students + Teaching process, which affects the teaching process.

The third model is the one which is being tested in the Gjirokastra district, to see : Does the introduction of ICT to the teaching process result in an increase in the quality of teaching process?

Data have been gathered in some urban and rural schools in the Gjirokastra district. These data have been gathered to assess the current state of the quality of teaching process in the schools and based on such data ideas to modify the current educational policies can be generated.

\subsection{Sample}

The study includes 12 schools of the city, six urban and six rural. Data from 260 classes containing 5,656 pupils have been analyzed. The data regarding the GPA of two subjects have been gathered, one is History the other Biology and Health Education.

\footnotetext{
${ }^{3}$ Talbott Ave. L., The Future Does Not Compute, (Sebastopol, Calif..: O'Reilly \& Associates, Inc.., 1995)

${ }_{4}^{4}$ Orstein, AC, Hunkins, FP, Curriculum, Fundamentals, Principles and Issues, ISPs, Tirana 2003.pg 556
} 
Table No. 3

\begin{tabular}{|c|l|c|c|c|}
\hline Nr. & \multicolumn{1}{|c|}{ Schools } & Nr. Of classes & Nr. Of pupils & The subjects using ICT \\
\hline 1. & Naim Frasheri & 14 classes & 309 pupils & History/Biology \\
\hline 2. & Urani Rumbo & 12 classes & 311 pupils & History/Biology \\
\hline 3. & Andon Z. Cajupi & 12 classes & 249 pupils & History/Biology \\
\hline 4. & Koto Hoxhi & 30 classes & 822 pupils & History/Biology \\
\hline 5. & Pandeli Sotiri & 6 classes & 149 pupils & History/Biology \\
\hline 6. & Bularat & 6 classes & 34 pupils & History/Biology \\
\hline 7. & U.Kardhiqi & 6 classes & 101 pupils & History/Biology \\
\hline 8. & Dervician & 6 classes & 82 pupils & History/Biology \\
\hline 9. & Lunxheri & 6 classes & 142 pupils & History/Biology \\
\hline 10. & A.Zeneli fshat & 6 classes & 73 pupils & History/Biology \\
\hline 11. & A.Rustemi Lobohove & 11 classes & 216 pupils & History/Biology \\
\hline 12. & M.Gjollesha Lazarat & 15 classes & 182 pupils & History/Biology \\
\hline Total & 12 schools & 260 classes & $\mathbf{5 6 5 6}$ pupils & 2 subjects \\
\hline
\end{tabular}

\subsection{What are the criteria used for data collection}

- Schools / Teaching processes which have / use ICT infrastructure;

- Performance covering the period 2008-2012 (when the ICT infrastructure was made available)

- gth $^{\text {grades; }}$

- Use of ICT in Social Subjects (History) and Natural (Biology);

\subsection{What are the results and the trends observed? See the tables and charts below}

Table and Chart No.4

\begin{tabular}{|l|c|c|c|c|c|c|}
\hline & $2007-2008$ & $2008-2009$ & $2009-2010$ & $2010-2011$ & $2011-2012$ & $2012-2013$ \\
\hline History & 7.5 & 7.2 & 7.4 & 7.2 & 7.1 & 7.3 \\
\hline
\end{tabular}

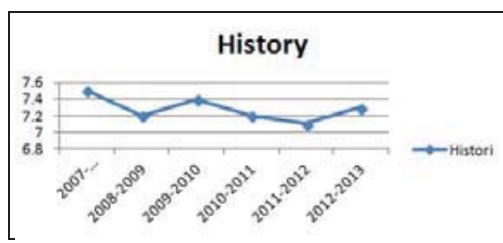

Table and Chart No.5

\begin{tabular}{|l|c|c|c|c|c|c|}
\hline & $2007-2008$ & $2008-2009$ & $2009-2010$ & $2010-2011$ & $2011-2012$ & $2012-2013$ \\
\hline Biology & 7.2 & 7.1 & 7.4 & 7 & 7.1 & 7.3 \\
\hline
\end{tabular}

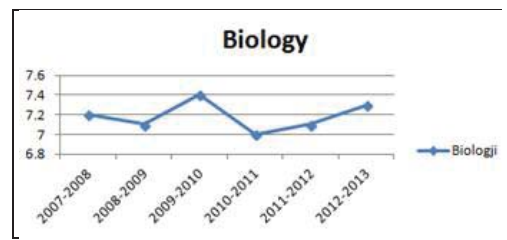

Table and Chart No.6

\begin{tabular}{|c|c|c|c|c|c|c|}
\hline & $2007-2008$ & $2008-2009$ & $2009-2010$ & $2010-2011$ & $2011-2012$ & $2012-2013$ \\
\hline Histo\&Biolo & 7.40 & 7.20 & 7.40 & 7.10 & 7.10 & 7.30 \\
\hline \multicolumn{7}{|c}{} \\
242
\end{tabular}




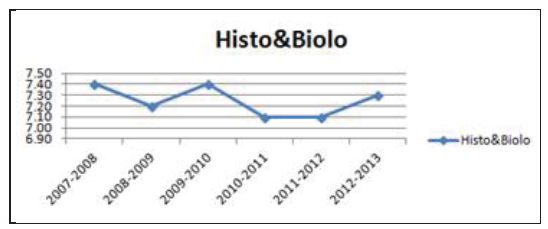

\subsection{What can be said as regards what we observe above?}

There are three things which can be said:

- The use of ICT is not always associated with an increase in the quality but also with a decrease in quality;

- The effects of use of ICT are different within the classes in a school and among schools of the city;

- The paradox of correlation Use of ICT - Increase in the quality of Teaching process is observed not only in the social subjects ( History ) but also in the natural subjects ( Biology ).

\subsection{What can account for the level of quality observed?}

- Regarding the ICT - Teaching process relationship. Questions that need to be answered are: If we are to assume that schools in the districts apply ICT, can it be that the variation in the quality learning should be sought in the quality and standards of ICT infrastructure in schools?

If ICT infrastructure is according to the standards, can it be that the variation observed in quality should be sought in the degree and methods of its use by teachers and students?

- Regarding the variation in the learning process among schools. Questions that need to be answered are: If city schools show differences in the quality of learning, can it be that these differences may be attributed to differences in the quality of ICT infrastructure in schools?

If all the schools have ICT infrastructure according to the standards and if teachers and students are able to use ICT, can it be that the variation in the quality of learning process among schools should be sought in the role of teachers?

- Regarding the variation of learning process among subjects. Questions that need to be answered are: If the use of ICT should be equally effective in the social and natural subjects, can it be that differences in the performance in History and Biology should be attributed to the role and preparation of teacher , to the role and interests of the student, or the use and suitability of ICT materials?

To render the study more complete additional data, from two other cities Tepelenë and Permet, has to be collected so the results can have a greater impact on the education policy.

\section{Some Recommendations and Conclusions}

The use of ICT in class has its limitations, they consist in:

- Lack of teacher training

- Lack of software resources for students

- Lack of funds, because often the these devices cost a lot .

- Incompatibility between the programs.

The integration of technology in the classroom faces a lot of obstacles

During the process of turning technology into an integral part of the teaching process, teachers face several obstacles. Teachers can be fully aware of the importance of ICT in society in general, but are not aware of its usefulness in schools and in the teaching process (Barras \& Petko, 2007; Jimoyiannis, 12007).

The greatest difficulty is the need for training time and resources available for the teaching - educational process. Teachers need to learn to use the computer, but this takes time. Therefore, Ertmer (2005) suggests that teachers' beliefs constitute the " the last frontier " for a successful integration of ICT.

Training and lack of resources is another concern. Without computers in classrooms and appropriate software to support the teaching process, the integration would not be successful. When teachers are asked to integrate technology, they should keep in mind:

- To use innovative teaching tools such as computer and Internet. 
- To change the way they teach their students.

\section{References}

MES, "National Strategy of Pre-university Education 2004-2015", Tiranë, 2004, pg 17

Allan Horsten, Francis Hunkins, quoted work, Curriculum, pg 556

Talbott, St. L., The Future Does Not Compute, (Sebastopol, 4. 4.

Calif.: O'Reilly\&Associates, Inc.,1995)

Orstein, A.C, Hunkins, F.P, Curriculum, Fundamentals, Principles and Issues, ISP, Tiranë 2003. Pg 556

Barras, J.-L., \& Petko, D. (2007). Computer und Internet in Schweizer Schulen. Bestandsaufnahme und Entwicklung von 2001 bis 2007. In B. Hotz-Hart (Ed.), ICT und Bildung: Hype oder Umbruch? Beurteilung der initiative Public private Partnership - Schule im Netz (pp. 77-133). Bern: SFIB.

Ertmer, P. A. (2005). Teacher pedagogical beliefs: The last frontier in our quest for technology integration? Educational Technology Research and Development, 53(4), 25-39.

EUN Consortium. (2004). ERNIST ICT school portraits. 20 school portraits of innovative use of ICT in six European countries. Woerden: Zuidam \& zonen. 